\title{
Aggression and perceived national face threats in Mainland Chinese and Taiwanese CMC discussion boards
}

\author{
Dániel Z. Kádár, Michael Haugh and Wei-Lin Melody Chang
}

\begin{abstract}
:
This study examines manifestations of verbal aggression in an intergroup context between Mainland Chinese and Taiwanese on computer-mediated communication (CMC) discussion boards. We examine the role of perceptions of national identity and face in occasioning instances of aggression in Sino-Taiwanese online interactions. It will be argued that there is a fundamental difference between Mainland Chinese and Taiwanese ways of displaying aggression when discussing cross-Strait issues. While the Taiwanese use abusive terms in order to dissociate themselves from the Mainland Chinese in online discourse, the latter tend to associate themselves with Taiwanese through terms that subsume Taiwanese claims to a national identity within a broader pan-Chinese identity, thereby implicitly displaying a social claim of sovereignty and cultural supremacy over Taiwan. We argue that these differences can be traced to evaluations by Taiwanese of these associative moves as threatening to their perceived national face.
\end{abstract}

\section{Keywords:}

identity, face, verbal aggression, impoliteness, CMC, China, Taiwan

\section{Introduction}

The study of verbal aggression has in recent years garnered increasing attention in the rapidly growing field of impoliteness research. However, this interest in aggression, rudeness and other impoliteness-related areas has, following the general trend in politeness research, centred primarily on its occurrence in interpersonal interaction (Bousfield 2008; Bousfield and Locher 2008; Culpeper 1996, 2011). The study of verbal aggression or perceived impoliteness in the context of intergroup relations, in contrast, has received less attention. The move to studying impoliteness in various forms of computer-mediated communication (CMC) offers the opportunity to start addressing this imbalance. Online discussion boards, for instance, can provide a very large corpus of interactions spread across large networks of users that enable researchers to examine verbal aggression not only at an interpersonal but also an intergroup level of analysis. In order to examine the implications of verbal aggression and perceptions of impoliteness for intergroup relations, however, the traditional theorisation of face as a positive self-image attributed to individuals (Goffman 1967; Brown and Levinson 1987) needs to be complemented by a conceptualisation of face that is extensible to groups. Such a collective notion of face need not assume an essentialistic view of group identity, but instead can build on a discursive conceptualisation of identity as produced, enacted or performed in discourse (Blommaert 2005; Bucholtz 1999; Butler 1990). The value of examining perceptions of collective identities through the prism of face is that it highlights the crucial importance of recognition of such perceptions by others in intergroup contexts.

Online nationalistic discourse in and between groups of Mainland Chinese and Taiwanese offers a useful window into verbal aggression (and other aspects of) impoliteness in an intergroup context. There are long-term political strains between China and Taiwan: the Chinese Communist Party claims Taiwan is a part of China, while the Taiwanese reject this stance (Cole 2006). Due to this, Mainland Chinese and Taiwanese online interactions can become hostile when the two sides interact or if they discuss issues relating to national 
identity. In direct Sino-Taiwanese interactions even seemingly small issues such as the use of simplified or traditional Chinese characters (the former preferred in China and the latter in Taiwan) can lead to the outbreak of acrimonious debates. Such debates are arguably connected to the broader discourse on Chinese nationalism that surfaces, for instance, in the media in both countries (Gries 1999; Gries and Peng 2002; Kuo 2002, 2003). ${ }^{1}$

A focus on Chinese verbal aggression and impoliteness in intergroup contexts also addresses somewhat of a gap in the field: although some studies have touched on aggression, rudeness and other impoliteness-related areas (Kádár 2012; Pan 2000; Pan and Kádár 2011), impoliteness in Chinese is still considerably underrepresented in the literature, compared with politeness issues. Studies on relational work in CMC also reflect this imbalance: while various forms of CMC offer potentially massive datasets to examine conflict, rudeness, aggression and other phenomena associated with impoliteness, the few studies devoted to Chinese CMC have dealt predominantly with politeness (Chen 2009; Lu 2010), and other related phenomena (Su 2009; Wang 2009).

In this study, we examine manifestations of verbal aggression between Chinese and Taiwanese in computer-mediated communication (CMC) discussion boards. More specifically, we examine the role of perceptions of national identity and national face in occasioning instances of aggression in this particular intergroup context. While we argue that perceived threats to national face can occasion instances of verbal aggression, we propose that national face is of a different order of ontological reality compared to that of face in interpersonal interactions. National face arises, we will suggest, through the dynamic intersection of micro, interactional concerns with macro, sociohistorical discourses about national identity, where the latter are what give rise to the expectations that can play a constitutive role in interaction (Haugh 2009). In other words, we are not claiming that national face arises through interaction per se, but rather that perceptions of national face, and expectations that it be recognised by others, play a critical role in the interpretative and recipient design processes in micro-interactions between Mainland Chinese and Taiwanese, including in the deployment and interpretation of aggression.

More concretely we will argue that there is a fundamental difference between Mainland Chinese and Taiwanese ways of displaying aggression when discussing cross-Strait issues. As we will show, the Taiwanese tend to use considerably more abusive terms of address/forms of reference with regard to Mainland Chinese than vice versa. This raises the question as to what the Mainland Chinese users might do instead of using such abusive forms in online interactions, since we have no reason or evidence to believe that Mainland Chinese are more likely to avoid conflict than their Taiwanese counterparts. As closer analysis shows, the answer resides in their respective use of referential terms, which represent different, competing orientations to perceived national face We analyse these different orientations primarily by building on Bucholtz's (1999) framework of discursive association and dissociation in identity formation.

A comparative study of Taiwanese and Chinese online behaviours raises an important empirical question, however, namely whether the practice of internet censorship prevalent in Mainland China decreases the relative amount of Taiwan-related discourse. As Zittrain and Edelman (2003) have argued, among others, the Chinese government blocks top Taiwanese websites. This means that Mainland Chinese and Taiwanese often have no opportunities to interact directly on political issues, and so some of this aggressive discourse takes place in intracultural dialogues. Yet, as our paper will show, there have recently been an increasing number of Mainland Chinese CMC discussion boards which allow open access to Taiwanese users, and also there are cases where Taiwanese and Mainland Chinese encounter each other and start aggressive debates spontaneously in uncontrolled online gaming websites. 
In this paper, we begin by discussing the clash between Mainland Chinese and Taiwanese claims to national identity, and outlining how a notion of perceived national face can be usefully deployed in analysing online verbal aggression in intergroup contexts. We next briefly outline our data sources and methodological approaches before introducing the results of quantitative lexical research of the use of referential terms, including, in particular, abusive terms in online discourse. We then attempt to account for the asymmetry in the deployment of abusive terms by Taiwanese compared to Mainland Chinese through close analyses of micro-interactions between Mainland Chinese and Taiwanese in online discussion boards. We conclude by briefly outlining the implications of our findings for studies of identity and face in intergroup settings.

\section{Identity and national face in Mainland Chinese and Taiwanese CMC interactions}

The issue of national identity in cross-strait relations between Mainland China and Taiwan remains both highly sensitive and increasingly disputed (Chu and Lin 2001; Dittmer 2004; Hsu 2010; Huang 2009). While the official position in Mainland China is that Taiwan is a renegade province of China, many citizens of Taiwan no longer consider themselves to be (exclusively) Chinese. According to a recent poll conducted in 2008 by TVBS (a national television broadcaster in Taiwan), 45\% of respondents identified themselves as Taiwanese, 45\% identified themselves as both Taiwanese and Chinese, with there being only a very small minority of Taiwanese (4\%) who identified themselves as exclusively Chinese. ${ }^{2}$ As far as we are aware no similar poll has been conducted in Mainland China because Western-type census research does not currently occur under the authoritarian Chinese system (Pan 2012).

However, considering the pivotal role of ideological-political education in the socialisation of Chinese youth (Arai 2011), and the prevalence of discourse on Mainland Chinese and Taiwanese unity in the Chinese educational system, it seems to be logical to assume that a fair proportion of the Chinese population considers the Taiwanese to be Chinese. While no society is unanimous in its political discourse, which can also be seen from the fact that cross-strait discourses are not necessarily always hostile, it is likely that differences in national identity claims by Mainland Chinese and Taiwanese users are likely to surface in CMC discussion boards.

While CMC was initially seen as an impersonal and impoverished form of communication, in recent years there has been an important shift towards a discursive perspective on interpersonal dimensions of CMC, where identities are treated by analysts as performed and transient (Georgakopoulou 2006: 548), and evaluations of im/politeness are seen as arising locally in interactions within the context of communities of practice (Graham 2007), or latent/emergent networks (Locher 2006). The discursive shift in CMC research entails a shift away from researchers coding forms and strategies as straightforward instances of politeness or claims about particular identities, to an analytical focus on "expectations and norms about what is licensed, encouraged or prohibited", on the one hand, and what "social actions and practices [participants] are engaged in and their own evaluations of them", on the other (Georgakopoulou 2006: 552). However, while the discursive approach to im/politeness and identity accounts for variability in norms and interactional practices across online communities, the focus of research thus far has been primarily on relational work at the interpersonal level. It thus generally builds on an approach to identity and face rooted in the individual (Locher 2008) or relationships between individuals (Haugh, Chang and Kádár forthcoming). However, in studying conflict between identities at an intergroup level, which involve issues of national identity, current approaches to face cannot be straightforwardly deployed. An approach that complements the focus on the identity and face of individuals with an account of collective identities and face is arguably required. 
In regards to the analysis of collective identity, specifically, national identity, we take a broadly discursive perspective on national identity construction (De Cillia, Reisigl and Wodak 1999), although we prefer to treat national identities as perceived rather than imagined for the simple reason that perceptions of national identity held by individuals can nevertheless play a constitutive role in interaction. In analysing the differences in national identity claims by Mainland Chinese and Taiwanese CMC users we draw initially from Bucholtz's (1999) aforementioned concepts of association and dissociation. Associative identity practices involve indexing pan-identity claims. In Sino-Taiwanese interactions this pattern was found to be preferred by many Mainland Chinese who commonly claimed or assumed that Taiwanese are Chinese. Dissociative identity practices involve dissociating oneself from members of another nation. In our data this practice was more common amongst the Taiwanese users who claimed a Taiwanese national identity as independent of Mainland Chinese.

However, it was found that differential national identity claims could not readily explicate why the Taiwanese users displayed overt and covert forms of verbal aggression, while the Mainland Chinese users apparently did not. We thus turned to the notion of face, hypothesising that what occasioned displays of verbal aggression was the expectation that the claims of Taiwanese to a national identity independent of Mainland China should be recognised. When these claims were not recognised this was interpreted as a threat to the national face of Taiwanese. In invoking recognition of identity claims by others, then, we suggest that national identity claims are not only discursively constructed or disputed in discourse, but engender certain expectations amongst interactants. These expectations concerning recognition of national identity claims by others is what moves our analysis beyond a singular focus on identity to a consideration of face as well.

It has been noted that members of a particular ethnic group are often concerned about how members of other groups view them in general in intergroup contexts (Hahn and Hatfield 2011; Nwoye 1992; Sifianou 2011; Spencer-Oatey and Xing 2000). The notion of "group face” has thus been proposed to account for face sensitivities about groups to which individuals belong, ranging from smaller groups, such as families or workplaces, through to large groups, such ethnicities and nationalities (Spencer-Oatey 2005). While group face has often been theorised as “self-aspects of a person's identity that are derived from membership in a collective or group, and not...the identity of a group as a sui generis entity" (SpencerOatey 2005:106-107) or concern by individuals for group interests and norms (Nwoye 1992:313), we propose that in some instances a perceived group face goes beyond having implications for just the individuals who comprise that group. Morisaki and Gudykunst (1994), for example, claim that group face may be perceived as existing as a phenomena in its own right rather than being parasitic on "individual face" in "intergroup situations where there is an ongoing relationships [sic] between the groups involved" (p.73). In a number of East Asian societies, for instance, it is commonly assumed that "family face" or "company face" exists as an interactional concern alongside the faces of the individual members of that family or company (Hahn and Hatfield 2011; Haugh 2005), which builds, in turn, on a worldview where face and facework are not always assumed to be traceable to the self-image or identity of individuals (Arundale 2009). It follows from this latter assumption that members can perceive their group face to be threatened without this necessarily directly translating into a threat to their own individual face as members of that group. ${ }^{4}$

We propose here that this concept of collective or group face can be extended to a notion of perceived national face. Magistro (2007, 2011), for instance, proposes Brown and Levinson's (1987) notion of face be extended from Model Persons to Model Citizens in suggesting that the latter possess "a national esteem, a public national image which is commensurate to the sense of reputation that they attribute to their country and that they want others to appreciate [positive national face want] and respect [negative national face want]" 
(Magistro 2011:234). However, rather than theorising national face in terms of psychologised wants as does Magistro, we propose here that it is more consistent with a discursive stance on identity and impoliteness to theorise national face in terms of perceptions, which are variously distributed across the individuals that comprise a collective social network (in this case a nation state).

A discursive notion of national face builds first on perceptions (or beliefs) held amongst a particular group of individuals that they share some identifying characteristics that distinguish their group from (members of) other groups. In the case of cross-strait relations such perceptions might include the belief held by many Taiwanese citizens that Taiwanese are not (exclusively) Chinese, which contrasts with the belief held by many citizens of Mainland China that Taiwanese are Chinese; represented as "Taiwanese think that Taiwanese are not Chinese" and "Mainland Chinese think that Taiwanese are Chinese" respectively. At this point such perceptions involve identity claims rather than face per se. However, in intergroup interactions concern about the perceptions of the other group arguably become salient, in part due to the obvious political, economic and military power differential between Mainland China and Taiwan. In intergroup settings, then, it is not just the perceptions held by individuals themselves (direct perceptions) but also their perceptions of the perceptions of others (first-order reflexive perceptions), as well as their perceptions of the perceptions of others of their perceptions (second-order reflexive perceptions) that arguably come to play a constitutive role in interaction. In the case of cross-strait relations, first-order reflexive perceptions of national identity might include perceptions such as "Taiwanese think that Mainland Chinese think that Taiwanese are Chinese" or "Mainland Chinese think that Taiwanese think that Taiwanese are Chinese", while examples of second-order reflexive perceptions of national identity might include perceptions such as "Taiwanese think that Mainland Chinese think that Taiwanese think that Taiwanese are Chinese" or "Mainland Chinese think that Taiwanese think that Mainland Chinese think that Taiwanese are Chinese" and so on. It is these reflexive perceptions of national identity that underpin our claim that intergroup relations involve not only identity concerns but also collective face concerns. In other words, what differentiates face from identity is first that the former always involves expectations that it be recognised by others, and indeed without such (perceived) recognition there are no grounds for making a claim to face (Haugh 2009; O’Driscoll 2011); second that it inevitably involves reflexive perceptions of what others think of one's group and the like, not simply one's perceptions of one’s own group (Arundale 2010; Haugh and Hinze 2003); and third that it is inherently relational (Arundale 2006, 2010), among other things. This means that ultimately what distinguishes national face from national identity is that the former is occasioned by reflexive expectations that these identity claims be recognised by relationally significant others, while the latter only encompasses direct perceptions of national affiliation which do not depend (in an existential sense) on recognition from others.

It is worth noting, of course, that a focus on claimed national identity and perceived national face does not preclude discussion of the interpersonal or relational implications of such intergroup interactions (Mills and Kádár 2011). Obviously, when discussing CMC differences between mainland Chinese and Taiwanese it would be misleading to describe national identity and face-related conflicts as clashes between two massive online communities. Such a claim is all the more erroneous because while it is possible to observe certain rhetorical patterns in conflict, it is impossible to systematically describe the myriads of the differences among individual manifestations of behaviour. It is more productive in the ultimate analysis, we believe, to treat concerns for "group” and "individual” face not as dichotomous, but rather as dynamic, inter-related dimensions of an inclusive notion of face that is fundamentally relational in nature (Arundale 2009, 2010), although space precludes us here from developing such a line of argument further. ${ }^{4}$ In any case, while we make passing 
reference to the interpersonal concerns in our latter analysis, our focus in this paper is primarily on issues of national identity and perceived national face in online discussion boards, and it is to these issues that we now turn.

\section{Data and methodology}

The data in this study is drawn from two main sources: (1) web-based text written by Mainland Chinese or Taiwanese accessible via general search engines, and (2) online discussion boards frequented by Mainland Chinese and Taiwanese users. We used these sources in an interdependent way in the course of the following three steps:

1. Search of online discussion boards to identify the most popular abusive forms of address/reference;

2. General web search to examine the relative frequency of these forms;

3. And finally a discursive exploration of discussion boards, in order to better understand the localised usages of these forms in online interactions (and/or the reason behind their non-occurrence in some instances).

The analysis of abusive terms in the present research is based on the concept of word frequency (Yates 1996). In the initial phase of the present research we set out to examine Mainland Chinese and Taiwanese use of terms that insult or threaten the other group. After making a selection of the most salient abusive terms used by Mainland Chinese and Taiwanese on discussion boards, we narrowed the list down to fifteen forms of address/reference that were frequently used in online settings.

In the next step, we studied frequency of these expressions through general search of online texts written by Mainland Chinese and Taiwanese. It might have been fruitful to limit the analysis to vocative cases in discussion boards only. However, online Sino-Taiwanese aggression discourse often takes place in intragroup rather than intergroup settings, and in various modes of CMC. That is, in many cases the Chinese and the Taiwanese interact only with their fellow countrymen and women, and they refer to rather than address people from the other side. While in such interactions aggression is always present at least potentially, such aggression would be labelled in psychology as indirect rather than direct(e.g. Hess and Hagen 2006).Since indirect aggression is more frequent than its direct counterpart, studying referential cases helped us to overview the types and frequency of abusive language use in China and Taiwan in relation to the other side. It is worth noting that when analysing discursive behaviour we analysed manifestations of direct aggression only, since we were ultimately interested in how such terms are used in intergroup interactions.

We only analysed cursing terms in which either 'China' (Dalu 大陸 'mainland China') or 'Taiwan' (or other references to the countries) occurred, in the compound form 'China/Taiwan $+X$ ' and 'Taiwan $+X$ '. There are in fact two different official designations for China, namely the aforementioned Dalu and the official form Zhongguo (中國). Forms containing the latter (e.g. Zhongguo-gou 中國狗 'Chinese dog') were excluded from the analysis because while 'mainland' (Dalu) is inherently 'exclusive' (i.e., 'mainland' $\neq$ 'Taiwan' and other overseas Chinese communities), Zhongguo is 'inclusive' in that in certain ideological contexts it can refer to Taiwan as part of China; for instance, Zhongguo-gou ('Chinese dog') can refer to Taiwanese in certain contexts. There were also some 'ambivalent' terms that we excluded from the analysis such as si-hanjian 死汉奸 ('traitor of China who should die') as they are frequently used by both Mainland Chinese and Taiwanese. For example, while si-hanjian is mostly used by Mainland Chinese to abuse Taiwanese, in some cases it is also used by the Taiwanese. Finally, we restricted our research to forms that originate in standard Chinese; e.g. '426' is not counted in spite of the fact that it is fairly common in online discourse. ${ }^{5}$ 
After identifying fifteen abusive forms of address/reference, we conducted Google searches in order to observe their relative frequency. In what follows we outline how we constrained this lexical search with reference to Dalu-gou 大陸狗 ('mainland Chinese dog'), a common abusive form of address/reference used by Taiwanese:

- Imputed “大陸狗” (in quotation marks): 89,100 hits;

- Refined the search by inserting “Taiwan” (“臺灣”) and -Singapore (-新加坡), -Hong Kong (-香港), -Malaysia (-馬來西亞), etc., in order to ensure that the retrieved data only reflects Mainland Chinese and Taiwanese hits (in other overseas Chinese communities, including notably Hong Kong, there is also a prevailing anti-Chinese political discourse, see Mathews et al. 2008:171);

- Excluded compound forms in which the use of "mainland Chinese dog" could be nonabusive, e.g. -pet (-宠物), -veterinary (-医师), -dog meat (-肉), -dog species (-犬);

- Excluded cases where an abusive form occurred in reference to the other side's verbal abusive behaviour, that is, in situations when Chinese posters intend to generate antiTaiwanese sentiments or vice versa. This was done simply by limiting our Google search to either traditional (Taiwanese) or simplified (mainland Chinese) fonts. Considering that empirical research shows that few Taiwanese use simplified fonts and perhaps even less mainlanders use simplified ones, excluding abusive terms where the font is different to that of the surrounding text is likely to remove Taiwanese metapragmatic discourse on Chinese abusive language use, and vice versa, from the analysis. In other words, Taiwanese users of abusive terms were identified through their use of traditional Chinese characters, while Mainland users were identified through their use of simplified Chinese characters.

- Excluded cases in which the poster's/author's national identity cannot be defined with certainty. Although in the majority of the cases the orthographic method discussed above also helped us to ascertain whether the user was from Taiwan or Mainland China, there were a few scattered exceptions to this trend. For example, as we shall see in the case of extract 1 below, some educated Chinese netizens intentionally use traditional characters as a form of (potentially mock) association with the Taiwanese. Due to this, if there was any doubt with regards to the national identity of a netizen - that is, in cases in which this was not clear from the given utterance - we attempted to manually analyse textual and contextual clues.

- Manually checked the remaining hits to ascertain whether they in fact reflect Mainland Chinese and Taiwanese conflict; this final search resulted in roughly 53,600 hits.

While this lexical research is not fully precise in the sense that Google only retrieves estimated results, and is not necessarily always reliable, it does arguably reveal broad quantitative trends in the usage of such terms between Mainland Chinese and Taiwanese. While the recall rate of search engines is much debated (e.g. Zhu and Dreher 2008), through our manual check we were able to establish at least a centimal precision rate (see also Section 4). In any case, our focus was on the relative occurrence of these terms in Mainland Chinese versus Taiwanese online text, not absolute frequencies.

This lexical frequency analysis was followed by a discursive analysis of threads from online discussion boards containing instances of such terms. Messages posted to discussion boards are asynchronous and persistent, which means that multiple participants can view and respond to a single message or post. Discussion boards also provide for two-way anonymous message transmission, which makes them a potential hotbed for conflict since anonymity can lead to an increase in conflictive behaviour in online settings (Ishii 2010). The possibility of quoting in discussion boards also aids conflict because by repeatedly quoting a flaming 
message it is easier to keep the conflict active. The data studied exhibits considerable diversity in regards to various 'situation factors' (Herring 2007), including 'participant characteristics', 'purpose' and 'activity', which all differ to some extent across these online discussion boards. For example, in certain online communities abusive terms are used considerably more than in others. However, since we are focusing on threats to perceived national face, such variation was backgrounded in the collection of data, with the focus being mainly on ensuring the 'topic' and 'tone' of the discussion boards examined were relatively homogenous.

In undertaking more detailed qualitative analyses of threads at random from the online discussion boards, we followed Herring's (2007) "by theme” approach, that is, we selected topically interesting threads, namely, where there was metapragmatic discussion of SinoTaiwanese relations, and then analysed every message in a given thread. The data collected include roughly 30,000 Chinese characters. ${ }^{6}$ In order to understand the relative size of this dataset, it is pertinent to note that Chinese words are mostly constituted from one to three characters.

\section{Abusive terms in online discussion boards}

The present section first overviews the results of the quantitative analysis of the relative frequency of a number of abusive terms and then discusses the implications of these findings. As the present study aims to broad quantitative trends, with a particular focus on their relative frequency amongst Mainland Chinese and Taiwanese users, numbers in the tables are given in centimal. That is, in the course of this analysis we intentionally rounded numbers to the nearest 100: numbers which end as 50 or below are rounded below, and numbers from 51 are rounded above. This approach seems to be particularly reasonable given the previously discussed issues in regards to the recall rate of search engines, and also given our focus on relative rather than absolute frequency of occurence.

\subsection{Frequency of occurrence abusive terms}

Animal metaphors - most importantly 'pig' and 'dog' - were the most frequently used vocative forms of abuse, which is consistent with norms of Chinese rudeness in the political arena (Kuo 2003). The results of this lexical analysis are illustrated in the following tables, which introduce terms in pairs; that is, the Chinese and Taiwanese terms of abuse are represented in semantic pairs (where available).

\begin{tabular}{|l|l|l|l|}
\hline Term & $\begin{array}{l}\text { 1. Dalu-gou 大陸狗 } \\
\text { ('mainland China dog') }\end{array}$ & $\begin{array}{l}\text { 2. Dalu-zhu 大陸猪 } \\
\text { ('Mainland Chinese } \\
\text { pig') }\end{array}$ & $\begin{array}{l}\text { 3. Dalu-gui 大陸鬼 } \\
\text { (子) ('Mainland } \\
\text { Chinese devil’) }\end{array}$ \\
\hline Estimated frequency & 32,500 & 6,700 & 12,200 \\
\hline \multicolumn{3}{|l|}{} \\
\hline Term & $\begin{array}{l}\text { 4. Tai(wan)-gou 台(湾) } \\
\text { 狗 ('Taiwanese dog') }\end{array}$ & $\begin{array}{l}\text { 5. Tai(wan)-zhu 台(湾) } \\
\text { 猪 ('Taiwanese pig') }\end{array}$ & $\begin{array}{l}\text { 6. Tai(wan)-gui(zi) 台 } \\
\text { (湾) 鬼(子) } \\
\text { ('Taiwanese devil’) }\end{array}$ \\
\hline Estimated frequency & 12,900 & 7,100 & 2,500 \\
\hline
\end{tabular}

Table 1: 'Dog/pig/devil-group’ 
The first group includes a common group of compound terms - 'mainland China/Taiwan + dog/pig/devil' forms - which are used by both Mainland Chinese and Taiwanese users. Equating the enemy with a dog (gou), pig (zhu) or devil (gui) is a traditional practice in Chinese (Kádár 2007), and so these forms can be regarded as standard manifestations of abusive terms. In terms of their relative proportion, the Taiwanese seem to use these abusive terms more frequently than vice versa: while Tai(wan)-zhu 'Taiwanese pig' occurs slightly more frequently than Dalu-zhu 'Mainland Chinese pig', in sum there are 51,400 estimated occurrence of terms derogating Mainland Chinese, while there are only 22,500 occurrences of terms involving derogation of Taiwanese.

It should be noted that the dog/pig/devil-forms show some variation: 'Taiwan $+\mathrm{X}$ ' often occurs in the abbreviated 'Tai $+X$ ' form. Furthermore, in some cases gui 'devil' is combined with the nominal suffix zi 子 as in guizi. Gui vs. guizi are not necessarily interchangeable: guizi has connotations of more archaic usage, that is, Taiwan-guizi and Daluguizi occur more frequently in historical contexts.

\begin{tabular}{|l|l|l|}
\hline Term & $\begin{array}{l}\text { 7. Dalu-fen(fen) 大陸 } \\
\text { 糞(糞) ('mainland } \\
\text { China excrement') }\end{array}$ & $\begin{array}{l}\text { 8. Dalu-shi 大陸屎 } \\
\text { ('Mainland Chinese } \\
\text { excrement') }\end{array}$ \\
\hline Estimated frequency & 1,400 & 500 \\
\hline \multicolumn{2}{|l|}{} \\
\hline Term & $\begin{array}{l}\text { 9. Tai(wan)-fen(fen)台 } \\
\text { 湾粪(粪) ('Taiwan } \\
\text { excrement') }\end{array}$ & $\begin{array}{l}\text { 10. Tai(wan)-shi 台 } \\
\text { (湾)屎 ('Taiwanese } \\
\text { excrement') }\end{array}$ \\
\hline Estimated frequency & 400 & 100 \\
\hline
\end{tabular}

Table 2: 'Excrement-group’

A second group of abusive forms of address/reference are those that include 'excrement', i.e. fen(fen) 糞(糞) and shi 屎. ${ }^{7}$ In a similar way to the abusive terms in the previous groups, these expressions have historical predecessors (Kádár 2007), that is, equating the enemy with excrement is a traditional Chinese discursive practice. However, unlike the previous 'dog/pig/devil-group', these terms are rarely used in online texts. The rate of occurrence of Mainland Chinese and Taiwanese-related excrement terms is roughly equivalent to that of the 'dog/pig/devil-group', i.e. the Taiwanese seem to use these terms more frequently than the Mainland Chinese.

\begin{tabular}{|l|l|l|l|}
\hline Term & $\begin{array}{l}\text { 11. Zhina-zhu 支那豬 } \\
\text { ('China pig') }\end{array}$ & $\begin{array}{l}\text { 12. Zhina-gou 支那狗 } \\
\text { ('China dog') }\end{array}$ & $\begin{array}{l}\text { 13. Zhina-gui 支那鬼 } \\
\text { ('China dog') }\end{array}$ \\
\hline Estimated frequency & 154,500 & 15,700 & 2,300 \\
\hline
\end{tabular}

Table 3: Shina-group

A third group of frequently occuring abusive terms of address/reference used by Taiwanese in online CMC discussion boards is what have we defined as the 'Sina-group'. Shina 支那 (Zhina in Chinese), transliterated from Sanskrit, is a nationalistic term of contempt used in reference to Mainland China, which was widely used by the Japanese until the end of WWII 
(Fogel 1991). As Japanese was the official language in Taiwan until the handover of Taiwan to the Republic of China in 1945, in Taiwanese Mandarin 'Sina + X' loanword forms became a widely-spread form to express contempt for the Mainland Chinese. ${ }^{8}$ The popularity of these forms is explained by Taiwan's historical ties to Japan due to being a part of Japan for fifty years (1895-1945): in Taiwan there is a prevalent discourse on the cultural similarity between Japan and Taiwan at the cost of 'Chineseness' (Lam 2004), and this claim of cultural closeness manifests itself also in the use of 'Sina-terms'.

\begin{tabular}{|l|l|l|}
\hline Term & $\begin{array}{l}\text { 14. Tai-8-zi 台 8子 } \\
\text { ('Taiwanese bastard') }\end{array}$ & $\begin{array}{l}\text { 15. Si-a'gong 死阿共 } \\
\text { ('Commie to be } \\
\text { killed') }\end{array}$ \\
\hline Estimated frequency & 8,100 & 29,900 \\
\hline
\end{tabular}

Table 4. 'Taiwanese bastard'

Finally, there are two further abusive forms that have no equivalents. The first one, Tai-8-zi 台 8 子 ('Taiwanese bastard'), is a noteworthy form in that it is the only internet-specific term among the frequently used terms of abuse. 8-zi is a form of numeral slang for bazi 八字 ('bastard'), and as such is an interesting manifestation of so-called net-language (Crystal 2000:34). Si-a'gong 死阿共 ('Commie to be killed') is a militant form of reference to mainland Chinese and it seems to be frequently used by not only Taiwanese Chinese but also by Hong Kong users, although in the present study only use of the term by Taiwanese was included in the final count.

\subsection{Implications}

Quantitative research into frequency of abusive terms suggests that the Mainland Chinese use abusive terms much less frequently than the Taiwanese users. There were 255,700 Chinadirected abusive forms, but only 31,200 occurrences of Taiwan-directed abusive forms. In other words, abusive terms were directed at the Mainland Chinese eight times more frequently than at the Taiwanese. One could argue that this difference is due to the fact that we cannot hear the voice of Mainland Chinese online. However, if we look into statistical data it becomes evident that this is not the case. As recent data shows, Taiwan has a very high internet penetration rate (70.1\%), with an estimated 16,130,000 users. China has a considerably lower internet penetration rate (34.4\%), but the number of Chinese internet users is estimated to be up to $457,000,000 .^{9}$ As was already noted in the introduction, internet censorship does not influence Mainland Chinese discussions about Taiwanese issues. Furthermore, in light of the ruling Chinese Communist Party's attempts to maintain antiTaiwanese rhetoric both in the media and in online settings (Kalathil and Boas 2003), it seems unlikely that the Chinese authorities would censor displays of verbal aggression by Mainland Chinese towards Taiwanese, particularly in discussions of nationhood and national identity. The question thus remains as to why the Mainland Chinese do not use abusive terms as frequently as Taiwanese users.

In order to examine this further, we hypothesised that the use of pan-Chinese terms of reference by Mainland Chinese constitutes an associative identity practice, as it implicitly asserts sovereignty over the Taiwanese. Following an analytic methodology similar to the one used in estimating the frequency of abusive terms in online discussion boards, we searched for forms of address/reference that are typically used in pan-Chinese nationalistic discourse, including: 
- Taiwan tongbaomen 台湾同胞们 'Taiwanese compatriots’

- Dalu tongbaomen 大陸同胞們 'mainland Chinese compatriots'

- Taiwan xiongdimen 台湾兄弟们 'Taiwanese brothers'

- Dalu xiongdimen 大陸兄弟們 'mainland Chinese brothers'

- Taiwan pengyoumen 台湾朋友们 'mainland Chinese friends'

- Dalu pengyoumen 大陸朋友們 'mainland Chinese friends'

We searched the online occurrence of these expressions by excluding cases where they refer to fellow countrymen, by adding “+大陸” (China) to Taiwanese expressions, and +台湾 (Taiwan) to Chinese expressions, and the plural vocative pronoun (nimen 你們) to the search. We also refined the search by browsing only mainland Chinese websites for Taiwan-specific terms of association, and vice versa for Taiwanese terms. The frequency of occurrence of these terms after this search is shown in Table 5 below.

\begin{tabular}{|c|c|c|c|}
\hline Term & $\begin{array}{l}\text { 1. Taiwan tongbaomen } \\
\text { 台湾同胞 } \\
\text { 们’Taiwanese } \\
\text { compatriots' }\end{array}$ & $\begin{array}{l}\text { 3. Taiwan xiongdimen } \\
\text { 台湾兄弟 } \\
\text { 们'Taiwanese brothers' }\end{array}$ & $\begin{array}{l}\text { 5. Taiwan pengyoumen } \\
\text { 台湾朋友们 'mainland } \\
\text { Chinese friends' }\end{array}$ \\
\hline Estimated frequency & 730,200 & 45,200 & 573,800 \\
\hline Term & $\begin{array}{l}\text { 2. Dalu tongbaomen 大 } \\
\text { 陸同胞們 'mainland } \\
\text { Chinese compatriots' }\end{array}$ & $\begin{array}{l}\text { 4. Dalu xiongdimen 大 } \\
\text { 陸兄弟們 'mainland } \\
\text { Chinese brothers' }\end{array}$ & $\begin{array}{l}\text { 6. Dalu pengyoumen } \\
\text { 大陸朋友們 'mainland } \\
\text { Chinese friends' }\end{array}$ \\
\hline Estimated frequency & 92,100 & 700 & 132,500 \\
\hline
\end{tabular}

Table 5. Terms of nationalistic association

The frequency of these pan-Chinese terms in relation to Mainland Chinese and Taiwanese in online discussion boards is markedly different and contrasts directly with the occurrence of abusive terms. While there were 1,349,200 estimated occurrences of pan-Chinese terms used in reference to Taiwan(ese), there were only 225,300 occurrences of pan-Chinese terms used in reference to Mainland Chinese. We have no means of ascertaining how many of these terms occurred in aggressive contexts, but the overall difference in frequency of these terms illustrates that amongst mainland Chinese users they are considerably more common (up to six times more) than amongst Taiwanese users. In what follows, we closely examine threads from three different online discussion boards to illustrate the way in which Taiwanese users respond to these forms with overt or covert aggression, which, we will suggest, indicates that the Taiwanese users evaluate pan-Chinese terms of reference as threatening to their perceived national face.

\section{Perceived national face threats in online discussion boards}

In the course of analysing threads in our sample dataset of 30,000 characters we uncovered a general trend for associative forms used by Chinese to occasion both overt verbal abuse and 
covert forms of abuse in the form of "mock politeness" or sarcasm on the part of Taiwanese users. We identified 124 such interactions where the Taiwanese users appeared to evaluate forms of nationalistic association as offensive. ${ }^{10}$ In the following excerpt taken from a large online discussion board covering a wide range of issues, the use of an associative term (Taiwan tongbaomen) by a mainland Chinese user elicited both covert and overt forms of verbal abuse from Taiwanese users.

埃及醒了，台湾同胞们呢？？？？？

Post 1 (xxphone 發表於 2011-2-19 02:40 PM):

大陸是一黨專政，台灣人虽之以鼻。台灣民主執政，

可實際狀況也好不到哪去。[...]

Post 2 (qaz3wsxqaz3wsx 發表於 2011-2-19 02:48 PM):

我只想問

台灣人醒不醒干你們中共人民什關西? [...]

Post 8 (padypc 發表於 2011-2-19 05:11 PM):

貴國是否廷醒是取決於貴國人民的智慧 [...]

Post 10 (CVB151 發表於 2011-2-19 05:28 PM):

[...] 我們台灣同胞本來就是醒的，你們在中共統治下才要醒醒。[...]

Egypt revolted - what will our Taiwanese compatriots do? ? ? ?

Post 1 (xxphone):

Mainland China is a one party dictatorship, and the Taiwanese give it a snort of contempt.Taiwan is a democratic country, but in reality democracy is good for nothing

Post 2 (qaz3wsxqaz3wsx):

I would only like to ask

What on earth do you Communists have to do with whether Taiwan has revolted or not?

Post 8 (padypc):

Whether your precious country will revolt or not depends on your precious country's intelligence

Post 10 (CVB151):

We Taiwanese compatriots have already revolted; you are the ones who should revolt against the Chinese Communist Party

(Source: http://www.eyny.com/archiver/tid-5963376.html)

This interaction represents an open challenge to Taiwanese by a mainland Chinese user, xxphone, who appears to be aiming to flame a discussion by calling Taiwanese Chinese to 'revolt' like the anti-Mubarak protesters against their government, as well as by describing Taiwanese democracy in negative terms (post 1). Interestingly, the first Taiwanese responder, qaz3wsxqaz3wsx, focuses primarily on disputing the claimed Sino-Taiwanese relationship and not the other potentially offensive claims in post 2. That is, it seems that xxphone's use of the term Taiwan tongbaomen ('Taiwanese compatriots') is treated as the most salient offence 
in this interaction. The term tongbaomen here refers to both Mainland Chinese and Taiwanese (i.e. it is inclusive). It thus constitutes an instance of an associative identity practice, although it is open to question whether this was meant ironically or not considering the dissociative implications of the remainder of xxphone's post. However, this ironic reading of Taiwan tongbaomen does not appear to have been picked up on by the subsequent respondents, as the next few Taiwanese responders also react in a hostile manner to the question whether Taiwan should revolt while they continue to maintain qaz3wsxqaz3wsx's rejection of Sino-Taiwanese association using terms such as bieren-de-guojia 別人的國家 ('other countries'), which implicitly assert Taiwan's independence from Mainland China (data not cited). The wish to dissociate national identities becomes even more marked when the Taiwanese poster padypc uses the honorific form guiguo 貴國 ‘your precious country’ to refer to China (post 8). As argued in Kádár (2007), forms like guiguo are used in Chinese diplomacy in order to elevate other countries, and so in the present context this honorific form of reference presupposes dissociation between Taiwan and Mainland China. Through such marked deference the poster is able to convey sarcasm and contempt for the position of Mainland Chinese in regards to national identity, and so the post is open evaluation as a form of "mock politeness" (Culpeper 1996, 2011). This utterance is soon followed by another dissociative practice when a Taiwanese poster CVB151 reinterprets tongbao 'compatriot' (post 10): he refers to the Taiwanese group as "we Taiwanese compatriots" and to the Chinese as "you”. By using tongbao as an in-group (i.e. Taiwanese) self-reference and referring to the Chinese as "you", CVB151 makes it clear that the Chinese do not belong to his group of tongbao ('compatriots').

The Mainland Chinese poster's claim to a pan-Chinese national identity through the use of Taiwan tongbaomen ('Taiwanese compatriots') is interpreted by these respondents as neglecting the Taiwanese claim to a separate national identity. This occasions a threat to the perceived national face of the Taiwanese users, as it potentially generates reflexive perceptions on the part of the Taiwanese users that Mainland Chinese think that Taiwanese are Chinese (first-order reflexive perception). It further generates the perception on the part of the Taiwanese users that the Mainland Chinese think the Taiwanese think that Taiwanese are Chinese (second-order reflexive perception). Since how the Taiwanese users perceive the Mainland Chinese to perceive them is not in accordance with their national identity claim, namely, that Taiwanese are not (exclusively) Chinese, these reflexive perceptions can be evaluated as threatening to their perceived national face.

It is interesting to note that the Taiwanese reaction in this thread is a typical one, as can be shown with reference to metapragmatic discourse on the use of tongbaomen ('compatriots') by Mainland Chinese when used in reference to Taiwanese. For instance, in 2008, a Sino-Taiwanese discussion occurred on an online discussion board under the title Weishenme zai Taiwanren mianqian chenghu duifang wei tongbao jiu name lingren taoyan 为 什么在台湾人面前称呼对方为同胞就那么令对方讨厌 ('Why do the Taiwanese dislike it if they are called 'compatriots'?’). ${ }^{11}$ In this discussion, which took place on the open-access Mainland Chinese Tianya 天涯 bulletin board, the vast majority of Taiwanese posters strongly refused to be described as tongbao, making a wide variety of linguistic and political arguments about the impropriety of this expression in Sino-Taiwanese relationships.

In what follows, we examine two further case studies from CMC discussion boards, in which there is evidence that the associative implications of tongbao were interpreted as offensive by Taiwanese posters, in spite of the fact that the mainland Chinese posts were ostensibly "polite". Such cases are noteworthy because they further illustrate that associative identity practices are open to be evaluated as rude or offensive in the context of intergroup Sino-Taiwanese interactions. 
（2）艾，台湾同胞们，让你们见笑了

Post 1 (221.221.217.*2009-02-11 01:34):

来到这个吧, 才知道

台湾人为什么讨厌中国人

看到那么多中国人的帖子

我实在是无语了

面对真相，他们就是不相信

反而用低俗愚蚌的话语攻击你们

请你们多多包涵了,

不过不是每个中国人都是处在愚昧无知中的

只不过我们也没能力没办法,

想想如果你们生在中国

对吗?

Post 2 (兔兔 2009-02-11 01:38):

楼主:

谁是你同胞啊?

你是支那猪, 台湾人是台湾人。

少来花花肠子了。

Post 3 (151.80.235.* 2009-02-11 04:54):

兔兔也真的不用这么绝情呢,多一个朋友要比多一个敌人要要好..

大陆人是值得我们同情的.................即使敌人也需要我们的同情,,,

他们是共产党的牺牲品..........我们生活在自由世界的人.怎么可以和他们计较呢

Ah, Taiwanese compatriots, we ridiculed you.

Post 1 (221.221.217.*):

Only when I visited this discussion board did I realise

why the Taiwanese hate the Chinese

Seeing so many Chinese posts

I lost my word

In fact, these Chinese posters don't trust [you]

and they use nasty words to bully you

Please be so kind to forgive us

in fact not every Chinese is as ignorant as those posters are

we can't do anything against this,

Imagine if you were born in China [like them]

Right?

Post 2 (Tutu):

Who is your compatriot?

You are Sina-pigs and the Taiwanese are Taiwanese.

Refrain from using cunning words.

Post 3 (51.80.235.*):

Tutu, you don't need to be so cruel, it is better to make friends than enemies.. 
Mainlanders deserve our sympathy even the enemy deserves our sympathy ,,,,

They are the victims of the Communist Party, while we are living in a free world. Why would it make sense to dispute things with them?

(Source: http://www.ipobar.com/read.php?tid-49099.html\#appear)

This interaction took place in the politics section of a large Taiwanese online discussion board that was accessed by a Mainland Chinese poster (221.221.217.*). The thread above begins with a collective apology by 221.221.217.* for the behaviour of other Mainland Chinese users who are critical and aggressive towards Taiwanese in many postings.

221.221.217.*'s pragmatic act is seemingly "polite” from the perspective of a traditional Brown and Levinsonian (1987) interpretation: apart from the apology itself, 221.221.217.* makes use of different formulaic expressions of politeness such as deferential request (qing 请 'please'), a formal expression of apology (duoduo-baohan 多多包涵 'kindly forgive us'), and denigrating terms in reference to mainland Chinese (yumei-wuzhi 愚昧无知 'be stupid and ignorant') (post 1). However, the next poster Tutu reacts to this apology in an aggressive way: Tutu criticises 221.221.217.* for calling Taiwanese tongbao 'compatriot' by first posting a rhetorical question, "Who is your compatriot?", which implies rejection of the inclusive connotations of tongbao (post 2). Tutu further describes the ostensibly polite post as an instance of huahua-changzi 花花肠子 ('cunning words'), as well as invoking the abusive referential form Zhina-zhu ('Sina-pig'). This negative evaluation of 221.221.217.*'s initial post is reiterated by the next poster, 51.80.235.*, who is more covertly aggressive in contrast to Tutu. In post 3 the user pretends to admonish Tutu for responding in such a harsh way to 221.221.217.*'s post, and also expresses sympathy towards the Mainland Chinese. However, this user formulates this post in an ironic way, as s/he refers to the Mainland Chinese as the "enemy" (diren), and it thus appears to be another instance of "mock politeness" (Culpeper 1996, 2011). In this way, the third post reinforces the second poster's attempt to dissociate Taiwanese from Mainland Chinese. Once again we suggest that what occasions these overt and covert displays of aggression on the part of the Taiwanese users is the threat to their perceived national face that the use of inclusive, pan-Chinese terms represents. ${ }^{12}$

The interaction above illustrates that the use of such terms by Mainland Chinese are often evaluated as aggressive, sometimes even independently of the poster's putative intention to be polite. The next interaction - in which Chinese and Taiwanese posters meet in a relatively apolitical context - further illustrates the national face-threatening potential of such expressions of association:

\section{台湾同胞们，请看帖子！}

Post 1 (疯狂海军 07/19/2010 02:30:25):

本是同根生，相煎何太急!

各位台灣同胞！請你體諒我們大陸玩家！我們視你們為兄弟姐妹，你們何故要 傷害我們呢?

不說政治的話題，說說歷史！你知道在遙遠的歷史我們本是一個祖先？我們都 是炎黃的子孫後代！為何不團結一起呢？高麗棒子在我們教訓他們，但是他們 分開了何必要重言自己的同胞們呢？我們都是一家人，從過去到現在都是！我 們要團結不能被外人的搗鼓導致我們的分裂！ 台灣的兄弟姐們！我們永遠都是 一家人！以後可不能因為一點小事就這樣惡言傷人了！团结一致、共同游戏！

Post 2 (Zart 1. 07/19/2010 09:25:56): 
第一.

兩岸只有文化根基相同,長期的隔離與發展後,我們不覺得跟你們是什麼所謂的兄 弟姐妹,更別提貴國政府與人民經常性的擺出侵略性、攻擊性的態度 [...]

所以拜託什麼認親大會請先去非洲谷地辦吧...請認清國際現實

第二.

懇請兩岸問題與種族問題請勿一再拿到 battle.net 這類中立區域來討戰, 這會造成 BZ 管理員的困擾 [...] 這裡是遊戲版面...

Post 3 (Deltablue 2. 07/29/2010 07:14:29):

[本是同根生] [各位台灣同胞] [本是一個祖先] [都是炎黃的子孫] [我們都是一家

人，從過去到現在都是]

在我看來全部是[文化侵略]

我們不希望在遊戲上談論 [政治] [兩國(岸)關係] 這種 [文化侵略] 也別來了 好嗎??

Taiwanese compatriots, please read this post!

Post 1 (Fengkuang Haijun [Insane Navy]):

We have the same national roots, so why we should shoot on each other so quickly? All Taiwanese compatriots! Please forgive us mainland Chinese players! We are your brothers and sisters, why should you harm us? This is nothing to do with politics, it is all about history! Don't we have the same ancestors? We are the descendants of the Mythical Emperors! Why don't we unite? Let us give a lesson to those [South] Korean hoodlums who cannot unite with their compatriots [i.e. North Koreans]. We are members of the same family, from ancient times until present. We should unite and not let outsiders to divide us! Taiwanese brothers and sisters! We will always be a family! From now on we should not insult each other because of small matters. Let us unite and play together!

Post 2 (Zart 1):

Firstly: The two sides of the Taiwan Strait only have cultural relationship. We have been separated and developed separately for a long period, and this is why we don't feel that we are your so-called "brothers or sisters", not mentioning that your precious country and its citizens often display aggressiveness and hostility [...]

Therefore, if you wish to seek relational cords, we pray you to proceed to the wilderness of Africa to do this [in a maximum of isolation] ... Please don't be naïve about international relationships.

Secondly: I earnestly request you not to bring cross-Strait issues and ethnicity ever after into Battle.net's neutral discussion of war matters, as this may disturb BZ [i.e. Battle Zone] moderators. [...] This is a game discussion forum.

Post 3 (Deltablue 2.):

"Have the same national roots", "all Taiwanese compatriots", "have the same ancestors", "the descendants of the Mythical Emperors", "we are members of the same family, from ancient times until present"

In my view these are all terms of "cultural aggression".

Keep out "politics" and "cross-Strait” and all this kind of "cultural aggression” from our game, will you?

(Source: http://forums.battle.net/thread.html?topicId=25969523700andsid=5021) 
This interaction took place on a thread on the online game "battle.net's" discussion board relating to the simulated battle 'Decisive Battle for the Senkaku Islands' (juezhan Diaoyutai 決戰釣魚台), which is an island chain claimed by Taiwan, Japan and Mainland China. Importantly, while battle.net is a multilingual and multicultural game website and is officially politics-free, players sometimes do discuss real political matters on the discussion board on this website, although 'hostilities' do not generally stir metapragmatic debates or generate wider attention.

Here, Fengkuang Haijun's call to Taiwanese players - that is to 'unite forces' with Mainland Chinese players both in the game and in discussions relating to game - seems to be spontaneous. Fengkuang Haijun claims his post has "nothing to do with politics" (bu shuo zhengzhi de huati 不說政治的話題), and he also attempts to 'give face' to Taiwanese players/posters by performing a collective apology (in a similar way to the first post on the previous thread) on behalf of Mainland Chinese (Glinert 2010). However, his posting is received in an extremely critical way by other players. Altogether six players responded to this post, with all being critical (although due to space constraints we only cite two responses). In the first response by Zart (post 2), the term xiongdi-jiemei 兄弟姐妹 'elder and younger brothers and sisters' is rejected, similar to Tutu's rejection of tongbao in example 2. He also projects dissociation by not only explicitly rejecting a close Sino-Taiwanese relationship ("if you wish to seek relational cords, we pray you to proceed to the wilderness of Africa to do this [in a maximum of isolation]"), but also by using the honorific form of address guiguo ('your precious country'). He also projects relational distance from Fengkuang Haijun by using a wide variety of deferential forms such as baituo 拜託 ('pray you'). In this sense, he seems to follow the same pattern as padypc in example (1) and 51.80.235* in example (2), in projecting mock politeness, since the use of use such deferential forms is marked in a online context where such forms occur relatively infrequently. Zart's post is followed by one from Deltablue who evaluates Fengkuang Haijun's attempts to project association as a form of “cultural aggression” (wenhua-qinlüe 文化侵略) (post 3).

In sum, these threads illustrate that in Sino-Taiwanese interactions the Mainland Chinese users do not necessarily need to use explicitly abusive terms in order to be perceived as projecting threats to the perceived national face of Taiwanese users. This threat arises from (reflexive) perceptions on the part of the Taiwanese users that the Mainland Chinese users are neglecting or even rejecting the claimed national identity of Taiwanese as not (exclusively) Chinese.

\section{Concluding remarks}

The present paper has set out to examine Sino-Taiwanese use of abusive terms in online discussion boards. Our focus has been on terms of address/reference through which differences between Mainland Chinese and Taiwanese orientations to perceived national face threats manifest themselves. Further research thus remains to be done to explore other strategies in Sino-Taiwanese aggression discourse. One of our key findings in relation to referring expressions has been that the Taiwanese are more likely to apply terms that openly abuse the Mainland Chinese than vice versa. Furthermore, in Sino-Taiwanese interactions the Mainland Chinese are more likely to use associative identity practices, such as the ostensibly polite forms tongbaomen ('compatriots') or xiongdijiemei ('brothers and sisters'). On the other hand, the Taiwanese tend to respond with dissociative identity practices, such as the use of abusive terms, negative metapragmatic discourse on the use of such pan-Chinese forms of address/reference, marked use of deferential forms, as well as sarcasm. We interpret this difference to be a reflection of broader macro-discourses on national identity. The Mainland Chinese claim that Taiwan is a part of China, and many Mainland Chinese users reinforce this 
claim through the use of pan-Chinese reference terms. Considering China's increasing global and regional dominance, the Mainland Chinese assume the position of the powerful party in these interactions. The Taiwanese users, on the other hand, seem to prefer to dissociate their national identity from that of Mainland Chinese, and thus respond aggressively to threats to their perceived national face. We suggest, however, that further study in this area is necessary to shed more light on the relationship between threats to perceived national face in the context of intergroup settings, and interpersonal implications for relationships between participants that arise in such interactions. Our focus in this paper has been on the former, but this is not to say that that latter is not also of considerable importance in the context of Sino-Taiwanese relations.

\section{Notes}

${ }^{1}$ We are not claiming here that Sino-Taiwanese interactions on discussion boards are inherently hostile. While studying this issue is beyond the scope of the present study, cases can be found when various Chinese and Taiwanese groups make use of a 'pan-Chinese' national face in order to position themselves as 'allies', for instance.

${ }^{2}$ http://www.tvbs.com.tw/FILE_DB/DL_DB/even/200806/even-20080610175239.pdf (cf. http://en.wikipedia.org/wiki/Taiwanese_identity).

${ }^{3}$ The distinction between direct and first/second-order reflexive perceptions draws in part from Arundale's (2010) discussion of the different levels of face interpreting in Face Constituting Theory (FCT). Our approach here differs, however, in that we focus on perceptions of identity claims in intergroup contexts rather than interpretations of relational connection or separation in interpersonal settings, although we believe our approach is not inconsistent with that outlined in FCT.

${ }^{4}$ We are not claiming here that these different aspects of face are necessarily hierarchically ordered. Whether one or the other takes precedence is entirely a matter of locally situated contingencies.

${ }^{5} 426$ refers to mainland Chinese as in Taiwanese (Minnan) its pronunciation is close to si-alu 死阿陸 'mainlander to be killed'. From a cultural perspective this is a noteworthy expression: 426 is originally an 'unlucky number' (in Chinese, number 4 is unlucky, and in 4264 becomes significant as it is a middle value between 2 and 6), and so this negative meaning further increases 426's abusive value.

${ }^{6}$ Since these texts include alphabetical letters, emoticons and other forms, this figure is only a rough estimation.

${ }^{7}$ Fen frequently occurs in a reduplicated form, although single and reduplicated variants seem to convey similar meanings.

${ }^{8}$ It can be claimed that the three 'Sina-forms' are loanwords and not Taiwanese creations because all of these forms occur in historical Japanese texts (e.g. Shina-no-inoko 支那猪子 for the contemporary Taiwanese Zhina-zhu), and also a check of current use on the internet reveals that these forms also occur on contemporary Japanese websites.

${ }^{9}$ Source: http://www.internetworldstats.com/asia.htm. 
${ }^{10}$ Since this analysis is based on sampled data there are no claims, of course, that it is definitive, and the hypothesis we form here awaits testing in larger datasets.

${ }^{11}$ Source: http://bbs.city.tianya.cn/tianyacity/Content/333/1/15082.shtml.

${ }^{12}$ It remains an open question whether the original post was intended straightforwardly as a "polite" apology or whether this "polite" packaging in fact was also a covert form of aggression, the so-called "velvet glove" noted by Watts (1992), where aggression is masked by ostensibly polite formulations.

\section{References}

Arai, Kuniko. 2011. Political education in China: A study of socialization through children's textbooks. East Asia 3(3). 30-47.

Arundale, Robert. 2006. Face as relational and interactional: a communication framework for research on face, facework, and politeness. Journal of Politeness Research 2(2). 193-216.

Arundale, Robert. 2009. Face as emergent in interpersonal communication: an alternative to Goffman. In Francesca Bargiela-Chiappini \& Michael Haugh (eds.), Face, Communication and Social Interaction, 33-54. London: Equinox.

Arundale, Robert. 2010. Constituting face in conversation: face, facework and interactional achievement. Journal of Pragmatics 42(8). 2078-2105.

Blommaert, Jan. 2005. Discourse. Cambridge: Cambridge University Press.

Bousfield, Derek. 2008. Impoliteness in Interaction. Amsterdam \& Philadelphia: John Benjamins.

Bousfield, Derek \& Miriam A. Locher (eds.). 2008. Impoliteness in Language. Berlin \& New York: Mouton de Gruyter.

Brown, Penelope and Stephen C. Levinson. 1987. Politeness. Some Universals in Language Usage. Cambridge: Cambridge University Press.

Bucholtz, Mary. 1999. "Why to be normal?” Language and identity practices in a community of nerd girls. Language in Society 28. 203-223.

Butler, Judith. 1990. Gender Trouble: Feminism and the Subversion of Identity. New York: Routledge.

Chen, Yunting. 2009. Nianqing yidai zai Taiwan wanglu yuyan zhong de limao xianxiang [Politeness Phenomenon in Taiwan CMC by Young Generation]. Tainan, Taiwan: Cheng Kung University MA Thesis.

Chu, Yun-han \& Jih-wen Lin. 2001. Political development in 20th-century Taiwan: statebuilding, regime transformation and the construction of national identity. The China Quarterly 165. 102-129.

Cole, Bernard. 2006. Taiwan's Security: History and Prospects. London: Routledge.

Crystal, David. 2001. Language and the Internet. Cambridge: Cambridge University Press.

Culpeper, Jonathan. 1996. Towards an anatomy of impolitenessl. Journal of Pragmatics 25. 349-367.

Culpeper, Jonathan. 2011. Impoliteness: Using Language to Cause Offence. Cambridge: Cambridge University Press.

De Cilia, Rudolf, Martin Reisigl \& Ruth Wodak. 1999. The discursive construction of national identities. Discourse and Society 10. 149-173.

Dittmer, Lowell. 2004. Taiwan and the issue of national identity. Asian Survey 44. 475-483. 
Fogel, Joshua A. 1995. The Sino-Japanese controversy over Shina as a toponym for China. In Fogel, Joshua A. (ed.), The Cultural Dimension of Sino-Japanese Relations: Essays on the Nineteenth and Twentieth Centuries, 66-76. Armonk, New York: M.E. Sharpe.

Georgakopoulou, Alexandra. 2006. Postscript: Computer-mediated communication in sociolinguistics. Journal of Sociolinguistics 10(4). 548-557.

Glinert, Lewis. 2010. Apologizing to China: elastic apologies and the meta-discourse of American diplomats. Intercultural Pragmatics 7(1). 47-74.

Goffman, Erving. 1967. Interaction Ritual. Essays on Face-to-face Behavior. New York: Pantheon Books.

Graham, Sage L. 2007. Disagreeing to agree: Conflict, (im)politeness and identity in a computer-mediated community. Journal of Pragmatics 39(4). 742-759.

Gries, Peter Hays. 1999. A "China threat"? power and passion in Chinese "face nationalism". World Affairs 162. 63-75.

Gries, Peter Hays \& Kaiping Peng. 2002. Culture clash? Apologies east and west. Journal of Contemporary China 11. 173-178.

Hahn, Jee-Won \& Hunter Hatfield. 2011. Group face in Korea and the United States: taking responsibility for the individual and the group. Multilingua 30(1). 25-70.

Haugh, Michael. 2005. What does 'face' mean to the Japanese? Understanding the import of face' in Japanese business interaction. In Francesca Bargiela-Chiappini \& Maurizio Gotti (eds.), Asian Business Discourse, 211-239. Berlin: Peter Lang.

Haugh, Michael. 2009. Face and interaction. In Francesca Bargiela-Chiappini and Michael Haugh (eds.), Face, Communication and Social Interaction, 1-30. London: Equinox.

Haugh, Michael \& Carl Hinze. 2003. A metalinguistic approach to deconstructing the concepts of 'face' and 'politeness' in Chinese, English and Japanese. Journal of Pragmatics 35(10-11). 1581-1611.

Haugh, Michael, Wei-Lin Melody Chang \& Dániel Z Kádár. forthcoming. "Doing deference”: Identities and relational practices in Chinese online discussion boards. Language@Internet.

Herring, Susan C. 2007. A faceted classification scheme for computer-mediated discourse, Language@Internet 5. http://www.languageatinternet.de/articles/2007/761/Faceted_Classification_Scheme_for_C MD.pdf (accessed 10 January 2011).

Hess, Nicole \& Edward Hagen,. 2006. Sex differences in indirect aggression: Psychological evidence from young adults. Evolution and Human Behaviour 28. 231-245.

Hsu, Philip S. 2010. Between identity quest and risk aversion: lessons from the Chen Shuibian presidency for maintaining cross-strait stability. Journal of Contemporary China 19. 693-717.

Huang, Li-Li. 2009. Is the third way possible for peace? The dilemma of national identity in Taiwan and beyond. Peace Psychology in Asia 4. 249-274.

Ishii, Kumi. 2010. Conflict management in online relationships. Cyberpsychology, Behavior, and Social Networking 13(4). 365-370.

Kádár, Dániel Z. 2007. Terms of (Im)Politeness: On the Communicational Properties of Traditional Chinese (Im)Polite Terms of Address. Budapest: Eötvös Loránd University Press.

Kádár, Dániel Z. 2012. Historical Chinese face-work and rhetoric: A case study of epistolary refusals. Journal of Politeness Research 8(1). 93-110.

Kalathil, Shanthi \& Taylor C. Boas. 2003. Open networks, closed regimes. The impact of internet on authoritarian rule. First Window 8(1). http://firstmonday.org/htbin/cgiwrap/bin/ojs/index.php/fm/rt/printerFriendly/1028/949 (accessed 25 March 2011). 
Kuo, Saihua. 2002. “Is there only one China?”: Analyzing the rhetoric of Chinese nationalism in a newspaper article. Journal of Asian Pacific Communication 11(2). 287-303.

Kuo, Saihua. 2003. 'You're a little rabbit in a pack of foxes': Animal metaphors in Chinese political discourse. Journal of Chinese Linguistics. 31(1). http://cup.cuhk.edu.hk/ojs/index.php/JCL/issue/view/129 (accessed 24 March 2011).

Lam, Peng-er. 2004. Japan-Taiwan relations: Between affinity and reality. Asian Affairs 30(4). 249-267.

Locher, Miriam A. 2006. Advice Online. Advice-giving in an American Internet Health Column. Amsterdam: John Benjamins.

Locher, Miriam A. 2008. Relational work, politeness, and identity construction. In Gerd Antos \& Eija Ventola (eds.), Handbook of Interpersonal Communication, 509-540. Berlin \& New York: Mouton de Gruyter.

$\mathrm{Lu}$, Shuang-shuang. 2010. A tentative study of the impoliteness phenomenon in computermediated communication. Cross-Cultural Communication 6(1). 92-107.

Magistro, Elena. 2007. Promoting the European identity: Politeness strategies in the discourse of the European Union. Critical Approaches to Discourse Analysis Across Disciplines 1(1). 51-73.

Magistro, Elena. 2011. National face and national face threatening acts: politeness and the European constitution. In Bethan Davies, Michael Haugh \& Andrew John Merrison (eds.), Situated Politeness, 232-252. London: Continuum.

Mills, Sara \& Dániel Z. Kádár. 2011. Culture and politeness. In Dániel Z. Kádár \& Sara Mills (eds.) Politeness in East Asia, 19-44. Cambridge: Cambridge University Press.

Morisaki, Seiichi \& William Gudykunst. 1994. Face in Japan and the United States. In Stella Ting-Toomey (ed.), The Challenge of Facework: Cross-cultural and Interpersonal Issues, 47-93. Albany, NY: State University of New York Press.

Nwoye, Onuigbo. 1992. Linguistic politeness and socio-cultural variations of the notion of face. Journal of Pragmatics 18. 309-328.

O'Driscoll, Jim. 2011. Some issues with the concept of face: when, what, how and how much? In Francesca Bargiela-Chiappini \& Dániel Z. Kádár (eds.), Politeness across Cultures, 17-41. Basingstoke: Palgrave Macmillan.

Pan, Yuling. 2000. Politeness in Chinese Face-to-face Interaction. Stamford: Ablex.

Pan, Yuling. 2012. What are Chinese respondents responding to? A close examination of question-answer sequences in survey interviews. In Yuling Pan \& Dániel Z. Kádár (eds.), Chinese Discourse and Interaction, 152-175. London: Equinox.

Pan, Yuling \& Dániel Z. Kádár. 2011. Politeness in Historical and Contemporary Chinese. London: Equinox.

Sifianou, Maria. 2011. On the concept of face and politeness. In Francesca Bargiela-Chiappini \& Dániel Z. Kádár (eds.), Politeness across Cultures, 42-58. Basingstoke: Palgrave Macmillan.

Spencer-Oatey, Helen. 2005. (Im)politeness, face and perceptions of rapport: unpackaging their bases and interrelationships. Journal of Politeness Research 1(1). 95-120.

Spencer-Oatey, Helen \& Jianyu Xing. 2000. A problematic Chinese business visit to Britain: issues of face. In Helen Spencer-Oatey (ed.), Culturally Speaking, 272-288. London: Continuum.

Su, His-Yao. 2009. Reconstrucing Taiwanese and Taiwan guoyu on the Taiwan-based internet. Journal of Asian Pacific Communication 19(2). 313-335.

Wang, Yin-han. 2009. 'Posing into being': An exploratory study of Taiwanese girls selfportraiture online. In N. Carpentier, P. Pruulmann-Vengerfeldt, R. Kilborn, T. Olsson, H. Nieminen, E. Sundin \& K. Nordenstreng (eds.), Communicative Approaches to Politics and Ethics in Europe, 179-191. Tartu, Estonia: Tartu University Press. 
Watts, Richard J. 1992. Linguistic politeness and politic verbal behaviour: reconsidering claims for universality. In Richard Watts, Sachiko Ide and Konrad Ehlich (eds.), Politeness in Language. Studies in its History, Theory and Practice, 43-69. Berlin \& New York: Mouton de Gruyter.

Watts, Richard J. 2003. Politeness. Cambridge: Cambridge University Press.

Yates, Simeon. 1996. Oral and written linguistic aspects of computer conferencing: A corpus based study. In Susan Herring (ed.), Computer-Mediated Communication, 29-46. Amsterdam: John Benjamins.

Zhu, Dengya \& Heinz Dreher. 2008. IR issues for digital ecosystems users. Proceedings of the Second IEEE International Conference on Digital Ecosystems and Technologies 2008, 586-591. Available from: http://ieeexplore.ieee.org/xpl/freeabs_all.jsp?arnumber $=4635203$.

Zittrain, Jonathan \& Benjamin Edelman. 2003. Empirical Analysis of Internet Filtering in China. http://cyber.law.harvard.edu/filtering/china/ 